\title{
Analysis of "Red Rose and White Rose" from the Perspective of Psychoanalytic Criticism
}

\author{
Min Yang \\ Xi'an FanYi University \\ Xi'an, China
}

\begin{abstract}
Zhang Ailing, as a legendary modern female writer in the history of 20th century Chinese literature, her writing features mainly the romantic story of the decline period of Shanghai, through the depiction and rendering of art, she gives humanity reflection and summary. "Red Rose and White Rose" is a representative work of Zhang Ailing's novellas. It was read by more and more people with a popular classic opening. The novel analyzes the split of modern urban personality, love, and desire with the relationship between the desire and marriage of a man (Tong Zhenbao) and two women (Red Rose Wang Jiaorui and White Rose Meng Yanli). This article will draw on Freud's critical theory and use psychoanalysis to analyze and interpret the characters of the novel.
\end{abstract}

Keywords-Zhang Ailing; Freud; id; ego; superego

\section{INTRODUCTION}

Introduction: "Perhaps every man has had such two women, at least two. If he married the red rose, and as time went by, the red changed into a faint trace of mosquito blood on the wall, and the white one still was "The moonlight in front of the bed"; If he married the white rose, the white became a rice stickies on the clothes, while the red one was a cinnabar on the heart." Those researchers who used to love Zhang Ailing mostly took this as the research keynote, to dig and analysis "Red Rose and White Rose" from different perspectives. For example, Song Zujian and others used feminist criticism to analyze the problems of women's tragedy, such as the low status of women, the consciousness of "female slaves", and the injustice of men and women which are the basic reasons to cause the women tragedy. ${ }^{1} \mathrm{Wu}$ Xiaofen and others used the semiotic method of French structuralist narratology theorist AJ Graimas to interpret the morality of the novel under the perspective of structuralist-semiotic criticism. ${ }^{2}$ Of course, there are scholars who share their opinions with other literary criticism methods such as social historical criticism theory and new criticism. What I want to do here is to analyze the character's psychology and insight into the author's psychology, and use psychoanalytic methods to re-interpret "Red Rose and White Rose". On one hand, we can more clearly understand

Song Zujian: "Analysis of the Female Tragedy of Zhang Ailing's 'Red Rose and White Rose"”, "Mang Zhong", No. 1, 2012 (Total 402).

Wu Xiaofen: " 'Rose' in the Wasteland: An Analysis of the "Symbol Rectangle" of Zhang Ailing's Novel 'Red Rose and the White Rose", "Modern Chinese- Chinese Modern and Contemporary Literature", July 2007. the character's psychology in the novel; On the other hand, analyzes the application of psychological theory in literary creation through Zhang Ailing's subconscious, hoping to provide informational help to future readers.

\section{THE MANIFESTATION OF FREUD'S ID}

\section{A. Tong Zhenbao}

Most of Zhang Ailing's novels write about women. "Red Rose and White Rose" is one of her few male-themed creations. Around the protagonist "Tong Zhenbao", there were four women who had entered his life, but only three of them had relations with him. The first was a Parisian prostitute. During his summer vacation when he studied abroad, he traveled alone to Europe. When he was passing through Paris, he stopped in Paris with the idea of "see how bad the Parisians were" and later he had sex with a local prostitute while was driven by libido and subconsciousness, this is another way for him to satisfy the ego. Does he have feelings with prostitute? Obviously not. There were only the original, native, unconscious id who was doing the blasphemy; Followed by the red rose, after Zhenbao returned home and worked in the British Hongyi dyeing and weaving factory in Shanghai, he was admitted to the home of his friend Wang Shihong. On the day of moving in, due to an unofficial and undecided meeting, Wang Jiaorui, Wang Shihong's wife, who "walked out of the inner room" and "was washing his hair" touched his heart, giving Zhenbao a strong interesting on her. This could be seen from his reluctance to wipe off the soap foam splashed on the back of his hand, and then naturally they had a relationship with each other. He was satisfied with this relationship and he was also silent in this id's "Happiness" principle. As described in the novel: Since then, Zhenbao sit on the top of the bus after work every day and run to his happiness facing the sunset; The last were the prostitutes he slept with, after he married the white rose Meng Yanli, due to the dissatisfaction of desires, he started to slept with prostitutes for joy. "He is not very picky about the prostitute's face. He preferred a little black and a little fat women. What he wanted was a fat humiliation." It can be seen how obviously Tong Zhenbao's id existence.

These actions of Tong Zhenbao are not moral and lack logical thinking. The only goal is to satisfy himself. In other words, the concept of the id is: "The only function of the id is to expel the excitement as soon as possible due to internal or 
external stimulation. All of the functions of id are the most basic principles of life realization."

\section{B. Red Rose - Wang Jiao Rui}

Wang Jiaorui is a woman who is unwilling to be lonely and emptied. Before she married Wang Shihong, she was fooling around by the name of finding people. "After a few years of playing, her fame gradually getting worse, so she grabbed Shihong in a flurry", and after married Wang Shihong she was restless and fooling around with Timmy Sun. Wang Jiaorui was never a passive woman, after Timmy Sun moved out, she took the initiative to ask him out, later because of Tong Zhenbao's appearance, she changed her love and began to "seduce" Zhenbao. In the process, she has no scruples, nor would she think of herself as a wife and should abide by the womanhood, she only seeks for happiness and joy. In Freud's words, her id promoted her enthusiasm, instinct, and habits and could only satisfy herself at all costs.

\section{White Rose - Meng Yanli}

If the red roses reflect the enthusiasm, passion, and debauchery of Wang Jiaorui, the white rose implicate the very different Meng Yanli's purity, boring and meekness. But even the so meekly Meng Yanli would also have the satisfaction and pleasure she want to pursue from unconsciousness, when she could not get her husband's "love," she chose to have a love affair with a small tailor who seems completely no match to her in the eyes of ordinary people". This accidental description we have to say that Zhang Ailing unconsciously or intentionally interprets the Freudian concept of id completely. This kind of instinct reflected in every character.

\section{EGO-RESTRAINT IN REAL LIFE}

\section{A. Tong Zhenbao}

The only one of the four women who did not have a relationship with Tong Zhenbao was his first love "rose". He loves her, it is true love, showing a proud, ego nature, and it is precisely because of this love, "so he compared the next two women with roses". In the face of true love, he is a man. "Rose's body came out of her clothes and jumped on him, but he was his own master". The description of this sentence we had to admit that Tong Zhenbao was the "Liu Xia Hui" in reality, when such a big attraction appeared, his self-restraint accounted for the top, in other words, the ego-restraint of Zhenbao defeated the desire of id. He attributed the rose to decent women. Such a woman is well-educated and can be married, but on second thought, "transplanted this kind of woman into his hometown society takes too much money and too much effort, it is a bad bargain". Since it is clear that there is no outcome, Tong Zhenbao insists on the "Reality principle" and judges and confronts rationally.

To Wang Jiaorui , Tong Zhenbao also had Ego-restraint. At first, although he had indiscriminate thoughts about Wang Jiaorui, "He gets down and goes picking up messy hair on the tiles", "He put it in his trouser pocket, and his hand stopped in his trouser pocket. He feels hot in whole body". But at that moment, his ego still controlled his id, "This kind of behavior is ridiculous after all. He took that group of hair out and put it into the spittoon gently". He also tried to resist his own desires, intentionally evaded Wang Jiaorui, arranged his younger brother to boarding school, and he went out to eat dinner and go home late while seeking new house to live. Even after the relationship took place, he was still constrained by the reality, he clearly understand that the woman was not the one he wants to marry so he insisted on breaking up, and married the "White Rose" that he should do in everyone's eyes.

\section{B. Wang Jiaorui}

Although Wang Jiaorui was an unrestrained woman, she fell in love with Tong Zhenbao. For him, she can change, she can give up, and she can even give up her id. This kind of love is the first time in Jiaorui's life. She doesn't know why she falls in love with Zhenbao. She often stares at him. There is tenderness in her eyes, and also slight laugh, laugh at him, also laugh at herself.

The description of this passage not only explains Wang Jiaorui's true love for Tong Zhenbao, but also writes out their contradictory feelings about this kind of cheating behavior. From the word "laugh at", it can be seen that Jiaorui even secretly glad that she found her love through this not-so-bright relationship. Just when Wang Jiaorui prepared a vigorous action for her id love, Tong Zhenbao said: "I think this matter cannot be reckless", "If you love me, you have to think of me". Tong Zhenbao thought that Wang Jiaorui is a married woman so it is safe and will not threaten himself to be a "good man". However, he did not expect Wang Jiaorui to write a letter to her husband. Faced with Tong Zhenbao, this ruthless selfishness, frightened, and only thinking for himself man, Wang Jiaorui did not stuck on him and tangled with him. She pondered for Tong Zhen Bao and thought for his mother so she chose to leave, despite being such reluctance, but she still bravely faced reality, chose to remarry, and lived on a quiet life. Isn't this the embodiment of ego function?

\section{Meng Yanli}

Even though Tong Zhenbao and Meng Yanli had chosen each other under the circumstances at that time, and become the "perfect match couple" in people's eyes. However, after marriage, Meng scrupulously abided by the women's path and was too obedient, even did not like the "best indoor sports", so she was left out in the cold. In the face of her husband's betrayal and neglect, she chose to be silent; in the face of her humiliation, she chose to take care of the overall situation; in the face of her desire to be discovered, she repented in time and no longer saw him. (Yu Ma said: "The tailor hasn't come for a long time. I don't know if he went to the countryside." "It's a young apprentice that comes") For a long time after her marriage, she tried her best to maintain Zhengbao's image of a "good man" with grievance and tried to restrain her own subconscious.

\section{THE SUPEREGO PERFORMANCE UNDER MORAL CONCEPT}

Although Tong Zhenbao has great controversy over love, he has the real superego performance in treating his family, 
colleagues and friends. Such descriptions are at the beginning of the novel:

Serving mother, no one is as thoughtful as him; promoting brothers, no one is as considerate as him; Working, no one is as enthusiastic and serious as him; No one is as loyal and selfdenying as him to treat friends.

In addition to helping the younger brother to find a job and pay back his gambling debts, he also takes care of his younger sister:

He has a problem younger sister. For her sake, he offers extra care for the single or the widowed friends, works for them, raises money and everything. Later, he spent a lot of hard work and introduced his younger sister to teach in a school in the Mainland, because he had heard that the male instructors there were all new college graduates and had not married.

From which we could see his thoughtfulness and precautions. Of course, there are ego-expressions among them, just as Freud's theories that the three are mutually exclusive and constraining influences, and not insulated or separated from each other, just see how to balance and highlight them. As Zhen Zhenbao, who has beaten the world with his bare hands and won a successful career, is because of his ideal adherence and superego pursuit, he has had the recognized social status by everyone; Because he wants to protect this "social status" he resolutely choose to broke up with Wang Jiaorui and married Meng Yanli; It was precisely because this "social status", at the end of the novel it writs: "The next day Zhenbao got up, changed his life, and became a good person again".

Besides that there are also multiple descriptions in the novel about Tong Zhenbao's self-esteem and vanity. For example, Wang Jiaorui called his office and they agreed drove to the movies after work. But he led the car to his colleague in need; and when he met Mrs. $\mathrm{Ai} \mathrm{Xu}$, his cover and guilty conscience were excellent embodiment.

\section{InSIGHTING AUTHOR'S PSYCHOLOGY FROM THE MAIN BODY OF THE NOVEL}

Freud believes that writers who are the subject of literary creation are actually the same people like neurotic patients. The process of literary creation also became the daydream of the artist. On this level, the characters and story ending of "Red Rose and White Rose" also reflect the state of mind of Zhang Ailing at the time of creation.

The novel was published in 1944, which was the love period between Zhang Ailing and Hu Lancheng. The 24-yearold Zhang Ailing fell in love with $\mathrm{Hu}$ Lancheng, a man who was 14 years older than her and already married. Zhang Ailing has always been arrogant in the eyes of everyone, but for her first love she showed her id. "As long as he was in Shanghai, $\mathrm{Hu}$ Lancheng went to see Ailing from early morning to late night. The man had tossed the land and the woman waste the weaving. They even did not want to travel together, they just have endless things to talk". So it can be seen that the love between them is fiery, but Zhang Ailing had also scolded the reality that $\mathrm{Hu}$ Lancheng had a wife. Her "ego" told $\mathrm{Hu}$ Lancheng not to come to see her again, but after Hu Lancheng guessed that the reason she said that is because she had fallen in love with him, later when he went to see her again, Zhang Ailing did not refuse. On the contrary, she was very happy. In fact, at the time, Zhang Ailing was actually a contradiction. "Red Rose and White Rose" may be a portrayal of her mood at that time. Although $\mathrm{Hu}$ Lancheng has a "white rose" in his home, he fell in love with Zhang Ailing this "red rose". Wang Jiaorui in the novel has stayed overseas, which is exactly in line with Zhang Ailing's experience. The fate of characters in the novel shows the fears and worries of Zhang Ailing at the time for her love. She was afraid that this hopeful love has no result, and $\mathrm{Hu}$ Lancheng will abandon her because of her social status, and fear the secular public opinion. I thinks that when Zhang Ailing wrote "Red Rose and White Rose", she concealed and mixed her own psychology and subjective feelings, no matter this kind of emotion was conscious or unconscious, it released all the sweetness and worry in Zhang Ailing's love at that time with literary carrier. The method has been vented to send emotions to the text and at the same time, it also reflected some social, moral and feudal issues combined with social factors of the time.

\section{CONCLUSION}

To sum up, the biggest tragic man in "Red Rose and White Rose" is Tong Zhenbao. The reason why I think Tong Zhenbao is a tragedy is because whether he sat down with the red rose to satisfy the id or meet the ego with the white rose, he was not satisfied in the complete sense and reached superego. Zhang Ailing's delicate and ingenious relationships and psychological descriptions reflect the analysis of the petty bourgeoisie's life and love, and reflect the human needs for emotions and some morbid realities. Han Xiao once commented on Zhang Ailing's novel: "Even if Zhang Ailing didn't take into account the theory of psychology when she was writing, her genius' technique has forced the readers to study his text in psychology in order to get confirmation".

Of course, there are still some limitations in using Freud's psychoanalysis to analyze "Red Rose and White Rose", which is to simplify the complex literary phenomenon. Just as that Zhang Longxi pointed out in his "Psychoanalysis and Literary Criticism": the psychoanalytic criticism separates literature from the social environment and cultural traditions that produce literature and simplifies the rich content into several concepts of psychoanalysis, which has changed literary criticism just like clinical diagnosis; and it cannot explain the aesthetic value of the work. It is also this fundamental limitation that led to the separation of Rong Ge from him and caused the criticism of most critics.

\section{REFERENCES}

[1] Dai Lili: "From the 'Red Rose and White Rose' to see Zhang Ailing's feminism", "Literature Review" (?). 代莉莉 : <从《红玫瑰和白玫 瑰》看张爱玲的女性主义>, 《文学评论》（？）。

[2] Qiu Yunhua, "Methods and Cases of Literary Criticism" (Beijing: Peking University Press, May 2006),P.83-112. 邱云华: 《文学批评 
方法与案列》（北京: 北京大学出版社, 2006 年 5 月）, 页 83112 。

[3] Ren Ruwen, Wang Yan: "Zhang Ailing Biography" (Beijing: International Culture Publishing Company, November 2010), P. 93-174. 任茹文, 王艳: 《张爱玲传》（北京: 国际文化出版公司, 2010 年 11 月) 页 93-174。

[4] Song Zujian: "Analysis of the Female Tragedy of Zhang Ailing's 'Red Rose and White Rose"”, "Mang Zhong", No. 1, 2012 (Total 402). 宋祖 建: 〈张爱玲《红玫瑰与白玫瑰》女性悲剧分析研究〉, 《芒种》 2012 年第 1 期（总 402 期）。

[5] Zhang Ailing: "Red Rose and White Rose" (Beijing: Taiwan Strait Press, April 1998), P. 3-47. 张爱玲: 《红玫瑰与白玫瑰》 (北京: 台海出 版社，1998 年 4 月），页 3-47。 